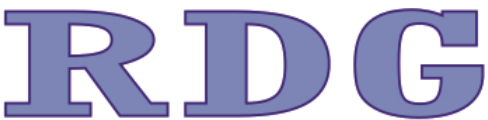

Revista do Departamento de Geografia USP
Revista do Departamento de Geografia

Universidade de São Paulo

www.revistas.usp.br/rdg

ISSN 2236-2878

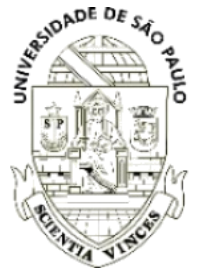

\title{
Analysis of Spatiotemporal Changes in Land Use and Land Cover in Sub-Watersheds of the Lower Itapecuru River in the State of Maranhão, Brazil
}

\section{Análise das Mudanças Espaço-Temporais do Uso e Cobertura da Terra nas Sub- Bacias Hidrográficas do Baixo Curso do Rio Itapecuru, Estado do Maranhão, Brasil}

\author{
Leonardo Silva Soares \\ Universidade Federal do Maranhão \\ leonardo.soares@ufma.br \\ Wilza Gomes Reis Lopes \\ Universidade Federal do Piauí \\ izalopes@uol.com.br
}

Antonio Carlos Leal de Castro

Universidade Federal do Maranhão

alec@ufma.br

Edson Vicente da Silva

Universidade Federal do Ceará

cacauceara@gmail.com

\author{
Gisele Cardoso de Araújo \\ Universidade Federal do Maranhão \\ gisacardoso@msn.com
}

Michelly dos Santos Moreira Universidade Federal do Maranhão michelly.m@outlook.com

Victor Lamarão de França Universidade Federal do Maranhão lamaraovf@yahoo.com.br

Karina Coqueiro Mendes Instituto Federal de Educação, Ciência e Tecnologia do Maranhão karinacoqueiro@hotmail.com
Resumo: Este estudo foi destinado para realizar uma análise detalhada da dinâmica espaço-temporal dos padrões do uso e cobertura da terra em dez sub-bacias hidrográficas localizadas no Baixo Curso do Rio Itapecuru, no Estado do Maranhão. A avaliação foi processada por meio do mapeamento de imagens Landsat-5 Thematic Mapper, referentes aos anos de 2005, 2010 e 2015, que foram adquiridas gratuitamente junto ao Instituto Nacional de Pesquisas Espaciais - INPE. Para o mapeamento, foram utilizadas as seguintes classes de UCT: ocupação (alta, média e baixa), vegetação (alta, média, baixa), solo exposto, agricultura, campo inundável e água continental. Os resultados mostraram que as classes "vegetação alta" e "vegetação média" foram predominantes nos três anos analisados. As principais mudanças foram evidenciadas nas $\mathrm{SBHs} 1,2$ e 10. Nas SBHs 1 e 2, foram impulsionadas pela supressão da vegetação durante a etapa de terraplenagem de empreendimento petroquímico localizado no Município de Bacabeira, enquanto que, na SBH10, o principal agente modificador foi a expansão das áreas ocupadas da cidade de Rosário. No entanto, num cenário futuro, existe a possibilidade da chegada de novos empreendimentos na região do $\mathrm{BCRI}$, os quais, irão potencializar a pressão sobre os recursos naturais das demais $\mathrm{SBHs}$, com a real possibilidade de ocorrerem mudanças significativa nos padrões de paisagem, gerando consequências negativas sobre a qualidade de vida das comunidades locais e funcionamento dos ecossistemas naturais. As informações obtidas sugerem o estabelecimento de estratégias de gerenciamento ambiental que antecipem a chegada de futuros empreendimentos, considerando a capacidade de suporte do ambiente e compatibilizando sua implantação com a manutenção das características socioambientais inerentes ao BCRI.
Abstract: The aim of the present study was to conduct a detailed evaluation of the spatiotemporal dynamics of land use and land cover patterns in ten sub-watersheds of the lower Itapecuru River in the state of Maranhão. The data were analyzed using Landsat5 Thematic Mapper images for the years 2005, 2010 and 2015, which were acquired free of charge from the Brazilian National Institute for Space Research. The mapping process involved the determination of the following classes of land use/cover: occupation (high, medium, low), vegetation (high, medium, low), exposed soil, agricultural enterprise, flood field and bodies of water. The results revealed that the classes "high vegetation" and "medium vegetation" were prevalent in the three years analyzed. Major changes were found in sub-watersheds 1, 2 and 10. The removal of vegetation during the excavation stage of the petrochemical plant located in the municipality of Bacabeira caused changes in sub-watersheds 1 and 2, while the main modifying agent in sub-basin 10 was the expansion of occupied areas in the municipality of Rosario. Future development in the region could impose further pressure on natural resources in other sub-basins, with the real possibility of significant changes in landscape patterns, generating negative consequences regarding the quality of life of local communities as well as the functioning of natural ecosystems. The present data underscore the need for environmental management strategies that consider the capacity of the environment to support future projects that are compatible with the social and environmental characteristics inherent to the region of the lower Itapecuru River.

Keywords: Landscape, dynamics, Land use/land cover, Geoprocessing, Environmental management. 


\section{INTRODUCTION}

Anthropogenic activities expand at an ever-increasing pace, causing major changes in natural ecosystems. This process generally begins with deforestation, followed by the implementation of activities related to land cultivation, road construction as well as urban and industrial expansion. Thus, there is an urgent need for the establishment of management strategies aimed at the territorial and environmental organization of geographic units. Botelho and Silva $(2010$, p. 153) recommend that "a river basin should be considered the basic unit of environmental analysis, as this would allow the assessment of the different components as well as the processes and interactions that occur within the basin". According to Miguel et al. (2012, p. 1089), a river basin "is a functional unit for understanding changes in land use and occupation". The analysis of this functional unit can guide strategies aimed at conservation and environmental planning. In this context, Souza, Galvani and Souza (2015, p. 56) state the following:

Transformations of the landscape caused by humans have diverse impacts on physical and biological realms. The identification, monitoring and rational guidance for land use and occupation are of the utmost importance to environmental planning.

Studies on the dynamics of land use and land cover (in river basins have been conducted in many countries to assist in the understanding of how changes in land use cause changes in the environment as well as to indicate development strategies aimed at ensuring sustainability (MENESES et al., 2015). According to the Brazilian Institute of Geography and Statistics (IBGE, 2013, p. 17), "knowledge on land use is paramount due to the need to ensure sustainability in the face of environmental, social and economic issues raised in the discussion on sustainable development".

According to Barros et al. (2013) the analysis of spatiotemporal dynamics of land use/cover patterns in watershed can offer information on levels of conservation, preservation and anthropization of the environment. To Shi et al. (2013) and Bezerra e Silva (2014) such evaluations allow mapping the areas of greatest susceptibility to erosive processes. Other research indicates that the maps are the basis for the analysis of integrity permanent preservation areas (REIS et al., 2012; NERY et al., 2013) and allow the identification/management of land use conflicts (MELO et al., 2010; PACHECO et al., 2014).

According to Demarchi and Zimback (2014, p. 103):

Land occupation for agricultural and urban activities requires adequate planning and knowledge on the characteristics of this natural resource, without which the resulting environmental impacts can have irreversible consequences and cause considerable harm with regard to social and economic aspects as well as the conservation of ecosystems.

Methodological approaches regarding the planning of river basis, which involve the interrelations of land use/cover patterns and both environmental and socioeconomic components in a given area, are indispensible to the development of land management strategies aimed at establishing recovery and conservation measures, with a consequent improvement in the quality of life of the population. However, even with this perspective, the growth of most cities and economic activities occurs in a disorderly fashion in the state of Maranhão, Brazil, often potentiating the loss of green areas and causing erosive processes, the deterioration of water quality and an increase in areas of risk. This situation exerts a direct influence on the quality of life of individuals, especially those with less purchasing power and which depends on natural resources for their survival.

This situation applies to the sub-watersheds of the lower Itapecuru River, especially those located in the municipalities of Bacabeira, Rosário and Santa Rita, where excavation activities were conducted between 2009 and 2013 for the implantation of a large petrochemical project, which led to significant changes in different components of the surrounding environment. After the excavation activities, construction was cancelled. However, the consolidation of the industrial district in the municipality of Bacabeira will lead to future industrial investments in the region, bringing risks to the landscape of the lower Itapecuru River. 
The aim of the present study was to evaluate land use/cover patterns in sub-watersheds of the lower Itapecuru River in the period spanning from 2005 to 2015 to determine changes in the landscape and offer data for the establishment of environmental planning strategies.

\section{ITAPECURU RIVER BASIN}

The Itapecuru River basin covers $53,216.84 \mathrm{~km} 2$, which corresponds to $16 \%$ of the area of the state of Maranhão (NUGEO, 2011). The basin is surrounded to the south and east by the Parnaíba River basin over the Itapecuru Hills, Azeitão Mesa and other small rises, to the west and southwest by the Mearim River basin and to the northeast by the Munim River basin (IBGE, 1998). According to Alcântara (2004), the different altitudes allow the classification of the Itapecuru River into upper, middle and lower courses (Figure 1).

The present study was focused on ten sub-watersheds located in the lower course of the Itapecuru River, covering an area of $421.6 \mathrm{~km} 2$ and situated in the municipalities of Rosário, Bacabeira and Santa Rita in the state of Maranhão, Brazil. The estimated population in the three municipalities is 93,227 inhabitants: 16,553 in Bacabeira, 41,694 in Rosário and 35,980 in Santa Rita (IBGE, 2015). Geographically, the sub-watersheds are located in the micro region denominated Itapecuru Mirim in the northern portion of the state approximately $50 \mathrm{~km}$ from the state capital São Luís and limited by the following coordinates: UTM 598658/574822 East and 9678715/9653145 North (Figure 2). The main accesses are through roadways BR-135 and BR-402, which interlink the municipalities to the state capital.

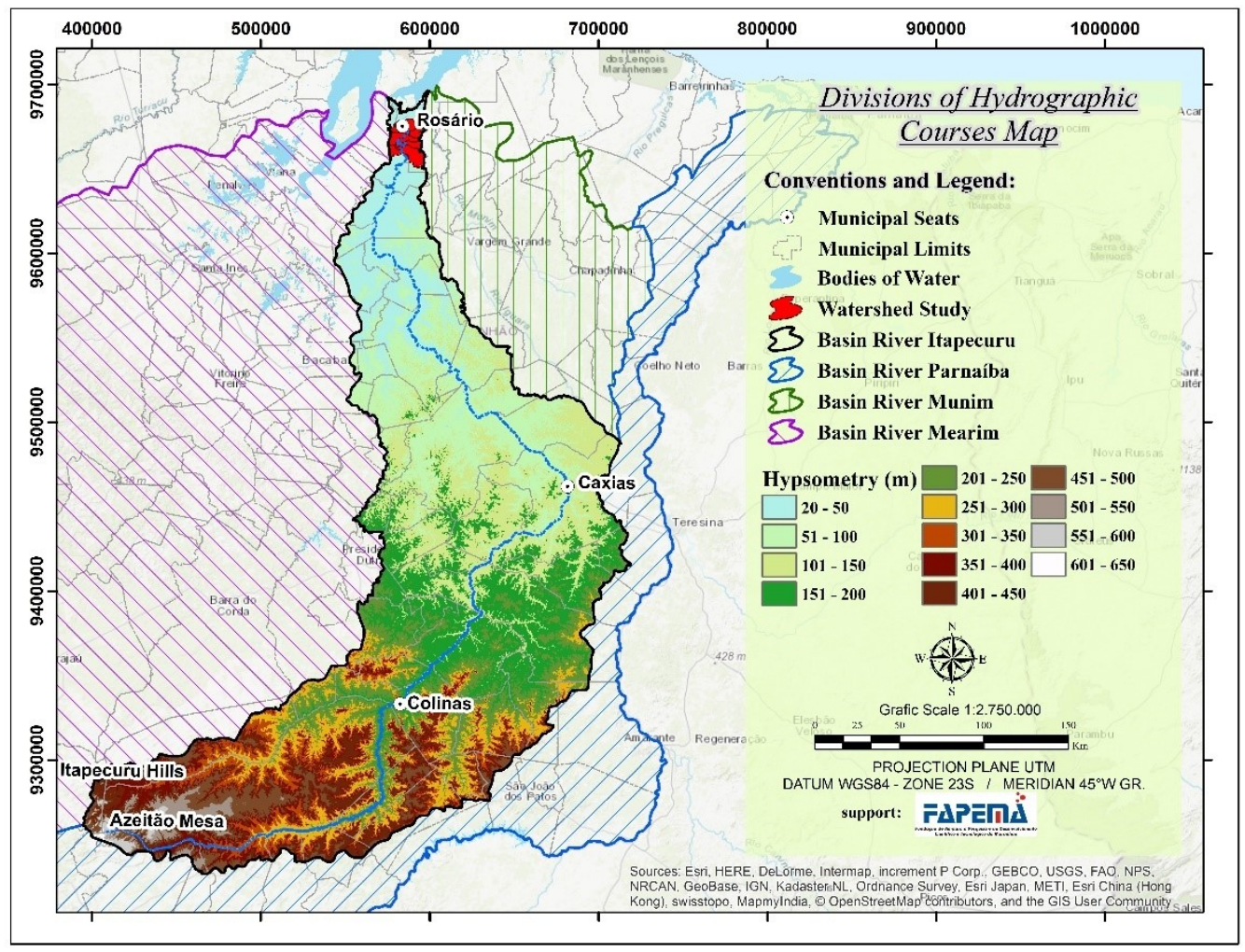

Figure 1: Location of Itapecuru River basin and altitudinal division into upper, middle and lower courses. 


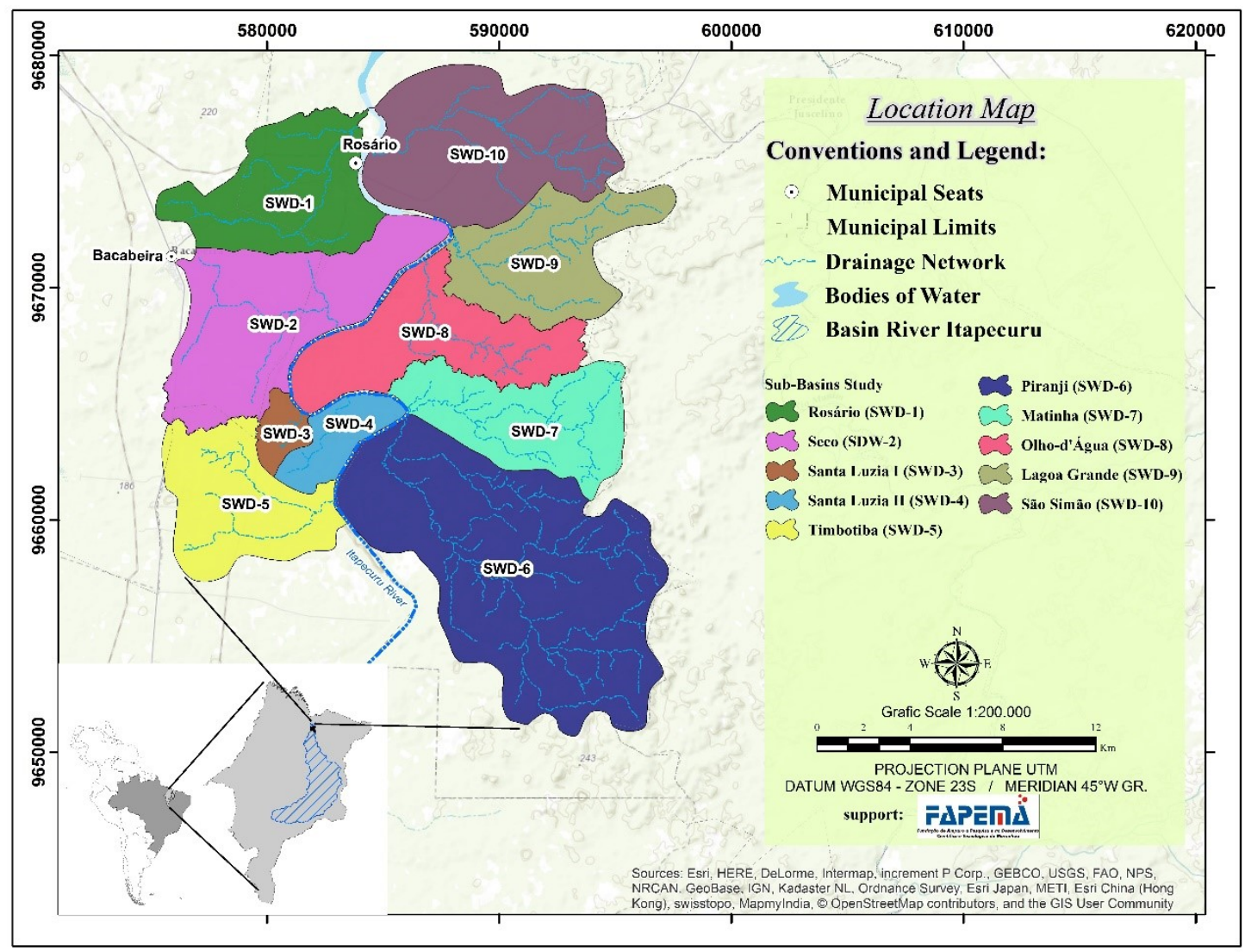

Figure 2: Location of sub-watershedsof lower Itapecuru River.

Production in the region is mainly related to industrial agriculture, civil engineering, the mechanical metal industry and the service industry (FSADU, 2013). Among these enterprises, only some agricultural, livestock and extraction activities are historically linked to the economic base of the municipalities of Bacabeira, Rosário and Santa Rita (IMESC, 2014). With the implantation of the work site for a large petrochemical enterprise and the creation of the industrial district of Bacabeira in 2008, the basis of the economy has been changed and new economic activities emerged in the region.

According to the Thornthwaite moisture index, the climate is humid (LABGEO, 2002). Mean annual rainfall (1975-2015) in the region is $1998.8 \mathrm{~mm}$. Two well-defined seasons occur. The rainy season spans from January to July and the dry season spans from August to December (INMET, 2015).

The soils in the area are under the influence of the sub-watershedsare dystrophic argilluvico plinthosol, concretionary petric plinthosol, dystrophic red-yellow argisol and dystrophic yellow latosol (IBGE, 2007). The topography is characterized as flat to mildly undulating, corresponding to a dry flat surface on which plateaus, low hills with somewhat convex tops (sometimes nearly mesas molded in sedimentary rock) and shallow valleys are located (FSADU, 2008).

\section{METHODS}

The first step was the acquisition of the cartographic data (digital format) from the websites of the Brazilian National Space Research Institute (INPE) and the Brazilian Institute of Geography and Statistics (IBGE). The cartographic basis used in the study for the creation of the databanks and thematic maps was constructed with the use of the following:

- Images from the Landsat-5 Thematic Mapper satellite (dates: October 22nd, 2005; August 15th, 2010; and August 15th, 2015), with a spatial resolution of 30 m (INPE, 2015);

- Information plan containing the roadway network of Brazilian municipalities in shapefile format referring to the year 2010 (IBGE, 2010);

- Data from the TOPODATA project, which offers a digital elevation model: pages 02s45 and 03s45 (INPE, 2008); 
- Databanks of the municipalities of Bacabeira, Rosário and Santa Rita (FSADU, 2009);

- Planialtimetric maps on scale of 1:100,000, pages 549 and 610 (DSG-SUDENE, 1980);

- Georeferenced Information Processing System (INPE), version 5.0.6;

- ArcGis 9.3 program of the Environmental Systems Research Institute, demo version

\section{a) Processing of satellite image and land use/coverage}

The evaluation of land use and coverage was based on mapping of the Landsat - 5 Thematic Mapper images for the years 2005, 2010 and 2015, which were acquired from the Brazilian National Space Research Institute. The satellite images were saved in TIF format and exported to GRIB format on the Geographic Information System (SPRING® 5.0.6) software designed by INPE. The images were imported and georeferenced based on control points for identification on the topographic map and image. After georeferencing, contrast functions were executed on the images to improve the visualization and highlight the classes of land use/coverage. The best composition consisted of bands 1, 2 and 3 of the 321/RGB composition. According to INPE (2009), this choice of contrast emphasizes the natural color of the image and vegetation appears in green tones. Table 1 lists the main applications, bands and spectral ranges used in the present study.

Table 1. Main applications and characteristics of bands of Landsat-5 TM sensor.

\begin{tabular}{lll}
\hline Band & Spectral range $(\boldsymbol{\mu m})$ & Main applications of LANDSAT TM sensor \\
\hline 1 & $0.45-0.52$ & $\begin{array}{l}\text { Considerable penetration in bodies of water with high degree of } \\
\text { transparency, allowing bathymetric studies; undergoes }\end{array}$ \\
& $\begin{array}{l}\text { absorption by chlorophyll and auxiliary photosynthetic pigments } \\
\text { (carotenoids); sensitivity to smoke clouds from agricultural } \\
\text { burning or industrial activity; may be attenuated by atmosphere }\end{array}$ \\
\hline \multirow{3}{*}{$0.52-0.60$} & $\begin{array}{l}\text { Considerable sensitivity to the presence of suspended } \\
\text { sediment, enabling analysis in terms of quantity and quality; } \\
\text { good penetration in bodies of water }\end{array}$ \\
\hline \multirow{3}{*}{$0.63-0.69$} & $\begin{array}{l}\text { Dense, uniform, green vegetation; considerable absorption, } \\
\text { becoming dark, enabling good contrast between occupied } \\
\text { areas (ex.: exposed soil, roads and urban areas) and } \\
\text { vegetation; good contrast between different types of vegetal } \\
\text { coverage (ex.: field, savanna and forest); enables mapping of } \\
\text { drainage network through visualization of riparian woodlands } \\
\text { and courses of rivers in regions with little vegetal coverage }\end{array}$ \\
\hline
\end{tabular}

Source: Image Generation Division (INPE, 2009)

The following classes of land use/coverage were employed for the mapping: human occupation (high, medium and low), vegetation (high, medium and low), exposed soil, agriculture, flood field and body of fresh water. The results of the mapping were converted into percentage values with the aim of identifying processes of change in the landscape of the sub-watersheds of the lower Itapecuru River.

Occupied areas enveloped zones of intensive use structured for buildings, residences and the road system where non-agricultural artificial surfaces predominated. For the best interpretation, these areas were subdivided into three levels of density: high occupation - zones with a large population, densely urbanized, with impermeable surfaces and areas with a certain degree of organization and infrastructure (housing units or neighborhoods); medium occupation - zones with a medium-sized population, with disorganized occupation and little or no infrastructure (areas of municipal expansion); and low occupation - zones with a low concentration of residences characterized by small to mediumsized properties.

Vegetation was classified into three typologies based on size and density: high vegetation - zones with closed arboreal/arbustive substrate and dense coverage; medium vegetation - areas of secondary forest in an advanced stage of regeneration; and low vegetation - arbustive (shrub) areas and those in an initial state of regeneration. Pastures were not considered in this category. 
Exposed soil represented areas with no vegetal coverage due to timber extraction or the development of agricultural, livestock and mining (sand extraction) activities. This category represented surfaces that were potentially more prone to erosive processes. The agriculture class included all cultivated lands, such as temporary or permanent farm land, silviculture and definitive agricultural areas, for which use was not identified during the mapping process. Flood fields were those that form along the floodplains of the Itapecuru River and are part of the sub-basin drainage system as a result of flood pulses in the rainy season and could include the presence of herbaceous vegetation. Bodies of water were all inland water resources and were represented by reservoirs and lakes in the sub-basins.

\section{RESULTS AND DISCUSSION}

Table 2 and Figure 3 display the mapping data for the year 2005. High and medium vegetation classes predominated, accounting for $77.76 \%$ of the mapped surface, which corresponds to 327.84 $\mathrm{km} 2$ of green areas. All sub-watersheds (SWDs), except SWD 1, had greater than $70 \%$ arbustive vegetal coverage. The low vegetation category accounted for only $4.85 \%$ of the sub-watersheds (20.46 km2) and was more evident in SWD 1, SWD 2 and SWD 5.

Table 2. Percentage (\%) of land use/coverage in sub-watersheds (SWDs) of lower Itapecuru River in 2005.

\begin{tabular}{cccccccccccc}
\hline Land use/occupation & SWD & SWD & SWD & SWD & SWD & SWD & SWD & SWD & SWD & SWD & TOTAL \\
classes & $\mathbf{1}$ & $\mathbf{2}$ & $\mathbf{3}$ & $\mathbf{4}$ & $\mathbf{5}$ & $\mathbf{6}$ & $\mathbf{7}$ & $\mathbf{8}$ & $\mathbf{9}$ & $\mathbf{1 0}$ & (2) \\
\hline Fresh water & 0.75 & 0.91 & - & - & 0.23 & 0.02 & - & - & 0.17 & 0.30 & 0.26 \\
Agriculture & 0.36 & - & 0.07 & - & 0.18 & 0.82 & 0.03 & 1.15 & 0.24 & 0.08 & 0.41 \\
Flood field & 2.20 & 0.49 & - & 3.66 & - & 2.58 & - & 3.58 & - & - & 1.37 \\
High occupation & 8.64 & - & - & - & - & - & - & - & - & - & 0.79 \\
Low occupation & 2.45 & 0.24 & 0.91 & 0.62 & 0.90 & 0.23 & 1.66 & 0.59 & 0.99 & 2.20 & 0.99 \\
Medium occupation & 1.16 & - & - & - & 0.35 & - & - & 0.38 & - & 1.91 & 0.43 \\
Exposed soil & 14.26 & 20.05 & 19.11 & 12.03 & 15.87 & 11.68 & 9.99 & 8.70 & 6.41 & 15.99 & 13.14 \\
High vegetation & 45.19 & 64.67 & 74.26 & 79.68 & 69.67 & 81.75 & 84.89 & 81.38 & 86.13 & 67.89 & 73.84 \\
Low vegetation & 17.61 & 7.89 & 1.46 & 4.01 & 10.49 & 1.30 & 3.36 & 1.89 & 2.79 & 3.65 & 4.85 \\
Medium vegetation & 7.40 & 5.75 & 4.19 & - & 2.32 & 1.62 & 0.06 & 2.33 & 3.27 & 7.97 & 3.92 \\
\hline
\end{tabular}

The occupation classes (high, medium and low) represented $2.2 \%$ of land use/coverage in 2005 , totaling $9.33 \mathrm{~km} 2$ of areas occupied by urban and rural communities. Individually, the highest proportions were found in SWD 1 and SWD 10, respectively accounting for $12.24 \%$ (4.75 km2) and $4.12 \%(2.31 \mathrm{~km} 2)$. These two sub-watersheds are the main axes of expansion in the municipalities of Rosário and Bacabeira.

The area of exposed soil in 2005 was $55.38 \mathrm{~km} 2$, corresponding to $13.14 \%$ of the study area, with the largest proportions found in SWD 6 (12.94 km2), SWD 2 (10.75 km2) and SWD 10 (8.97 km2). Agriculture accounted for $0.41 \%$ of the categories identified, totaling $1.71 \mathrm{~km} 2$ of areas used for the development of this activity. The pattern found for agriculture, characterized by small polygons associated with high and medium vegetation and randomly distributed throughout the sub-basins, suggests that this activity was primarily for the purposes of subsistence.

Flood fields accounted for $1.37 \%$ of the mapped surface $(5.79 \mathrm{~km} 2)$ in 2005 . This type of landscape is of extreme importance, as it represents the portion of floodplains of the Itapecuru and bodies of water of the sub-basins. Lakes and reservoirs accounted for only $0.26 \%$ of the sub-basins.

In 2010, areas of high and medium vegetation continued to prevail and respectively accounted for $70 \%$ and $10.48 \%$ of the surface of the sub-basins, corresponding to a total of $339.3 \mathrm{~km} 2$ (Table 3 and Figure 4). In comparison to 2005, the increase was $2.7 \%$, representing an additional $11.43 \mathrm{~km} 2$ of green areas in a five-year period. However, the inverse was found in SWD 2, where an $11.73 \%$ reduction in arboreal vegetation occurred between 2005 and 2010 (6.29 km2). Considering the ten sub-basins, the percentage of low vegetation was only $0.95 \%$ higher in 2010 in comparison to 2005, corresponding to an increase of $4.02 \mathrm{~km} 2$ of shrub vegetation. 


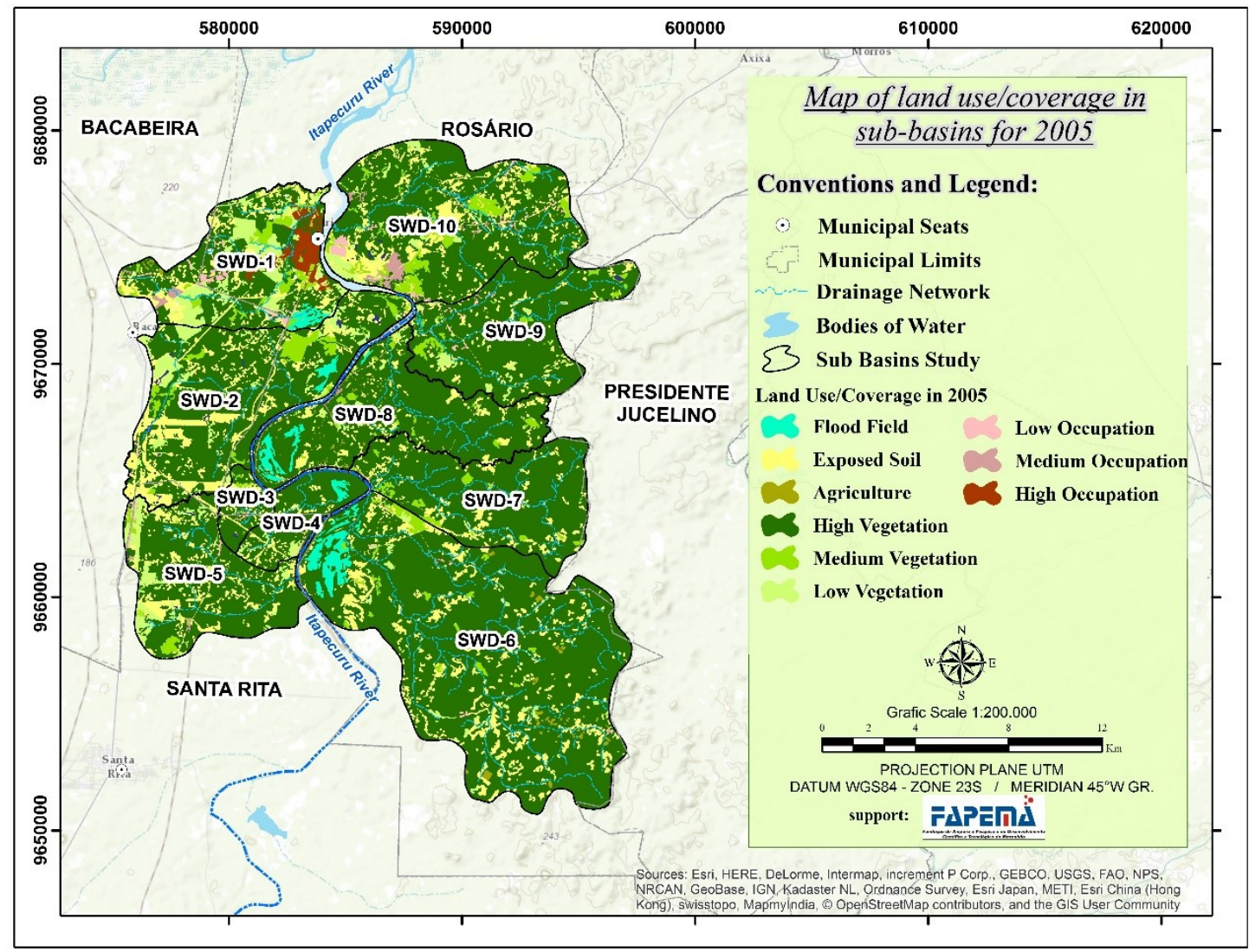

Figure 3: Map of land use/coverage in sub-watersheds of lower Itapecuru River for 2005

Table 3: Percentage (\%) of land use/coverage in sub-watersheds (SWDs) of lower Itapecuru River in 2010.

\begin{tabular}{cccccccccccc}
\hline Land use/occupation & SWD & SWD & SWD & SWD & SWD & SWD & SWD & SWD & SWD & SWD & TOTAL \\
classes & $\mathbf{1}$ & $\mathbf{2}$ & $\mathbf{3}$ & $\mathbf{4}$ & $\mathbf{5}$ & $\mathbf{6}$ & $\mathbf{7}$ & $\mathbf{8}$ & $\mathbf{9}$ & $\mathbf{1 0}$ & (1) \\
\hline Fresh water & 0.83 & 0.32 & 0.00 & 0.27 & 0.55 & 0.30 & 0.00 & 0.13 & 0.20 & 0.48 & 0.34 \\
Agriculture & 0.93 & 0.00 & 0.07 & 1.29 & 0.18 & 0.24 & 1.17 & 1.32 & 0.45 & 0.17 & 0.48 \\
Floodplain & 1.80 & 0.60 & 0.00 & 3.66 & 0.00 & 1.36 & 0.00 & 1.79 & 0.00 & 0.00 & 0.86 \\
High occupation & 11.45 & 0.00 & 0.00 & 0.00 & 0.00 & 0.00 & 0.00 & 0.00 & 0.00 & 0.35 & 1.10 \\
Low occupation & 3.49 & 0.51 & 0.69 & 1.18 & 0.26 & 0.23 & 0.69 & 0.75 & 0.40 & 1.65 & 0.89 \\
Medium occupation & 1.05 & 0.03 & 0.68 & 0.00 & 0.80 & 0.00 & 0.00 & 0.56 & 0.00 & 3.67 & 0.72 \\
Exposed soil & 12.01 & 29.33 & 10.99 & 6.26 & 11.68 & 4.41 & 1.50 & 4.11 & 2.38 & 10.17 & 9.33 \\
High vegetation & 34.19 & 47.16 & 63.37 & 32.62 & 69.15 & 83.64 & 92.00 & 62.88 & 90.15 & 76.21 & 69.99 \\
Low vegetation & 14.83 & 10.53 & 2.72 & 6.78 & 12.37 & 3.10 & 0.42 & 2.89 & 2.53 & 4.06 & 5.81 \\
Medium vegetation & 19.42 & 11.52 & 21.48 & 47.94 & 5.01 & 6.72 & 4.21 & 25.56 & 3.89 & 3.24 & 10.48 \\
\hline
\end{tabular}

The exposed soil class accounted for $9.33 \%\left(39.3 \mathrm{~km}^{2}\right)$ of the sub-watersheds in 2010 , which was a $3.81 \%$ reduction $\left(16.06 \mathrm{~km}^{2}\right)$ in comparison to 2005 , demonstrating the occurrence of the restoration of vegetal coverage in the lower Itapecuru River basin. In SWD 2, however, exposed soil increased by $9.27 \%$, accounting for $29.33 \%$ of the sub-basin area. This change corresponded to a reduction in total high and medium vegetation due to the removal of vegetation during the installation of the work site for the petrochemical enterprise in the municipality of Bacabeira.

In 2010 , occupied areas accounted for $2.71 \%$ of the sub-basins, totaling $11.42 \mathrm{~km}^{2}$, with the highest proportions in SWD 1 and SWD 10, in which occupied areas respectively accounted for $16 \%$ and $5.68 \%$ of the land. In comparison to 2005 , the increase was $0.5 \%\left(2.1 \mathrm{~km}^{2}\right)$, with the largest changes in SWD 1 and SWD 10, which were the sites of expansion in the municipalities of Bacabeira and Rosário. 


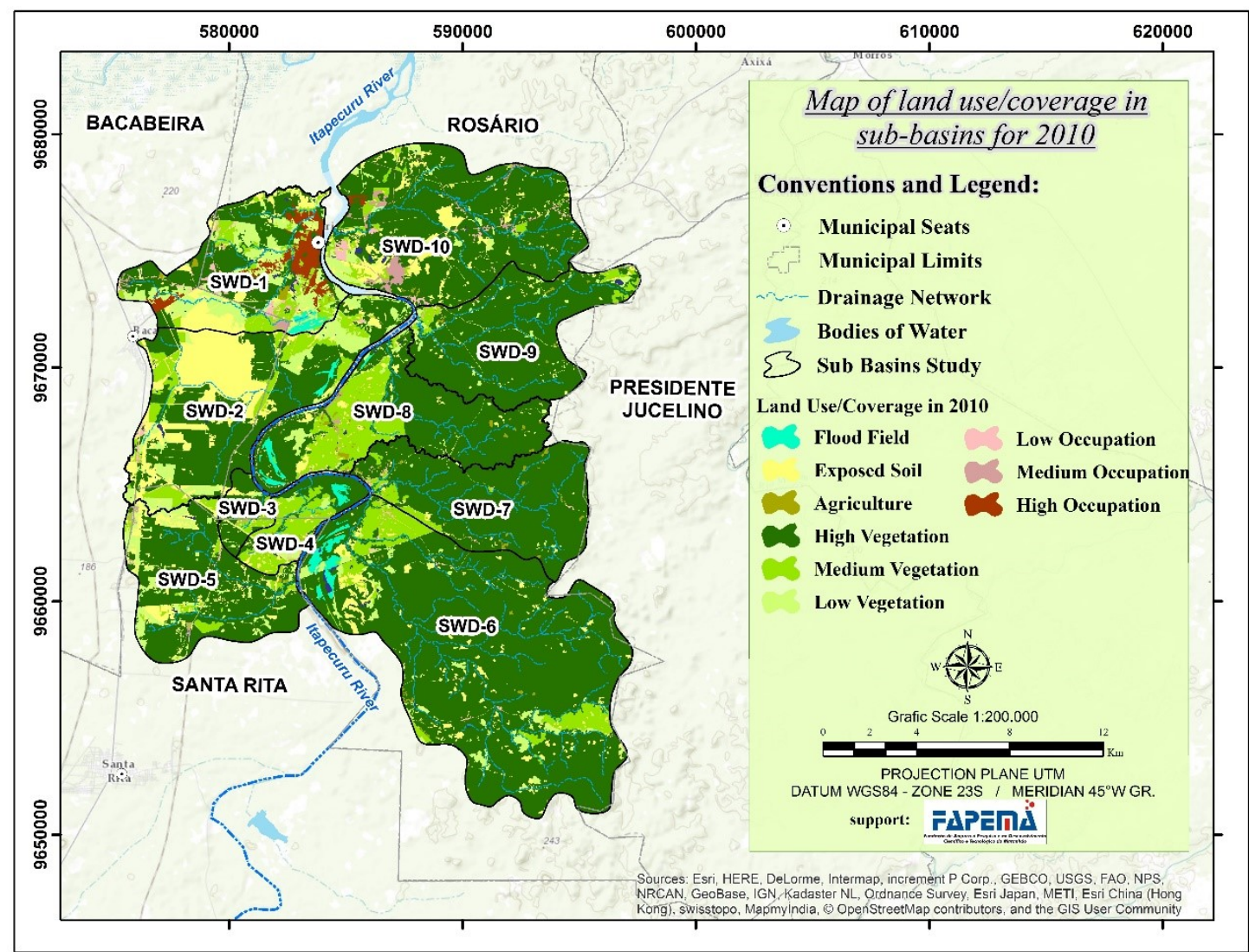

Figure 4: Map of land use/coverage in sub-watersheds of lower Itapecuru River for 2005-2010.

Agricultural activities accounted for $0.48 \%$ of the mapped area in 2010 , totaling $2.03 \mathrm{~km}^{2}$ of areas used for subsistence farming. This constituted a $0.2 \%$ increase in relation to 2005 .

Flood fields accounted for $0.86 \%$ of the mapped surface in 2010 , corresponding to $3.64 \mathrm{~km}^{2}$. The largest area of this landscape unit was found in SWD $6\left(1.51 \mathrm{~km}^{2}\right)$, followed by SWD $1\left(0.7 \mathrm{~km}^{2}\right)$ and SWD $8\left(0.7 \mathrm{~km}^{2}\right)$. The reduction in comparison to 2005 was $0.51 \%\left(2.15 \mathrm{~km}^{2}\right)$. Bodies of water accounted for $0.34 \%\left(1.43 \mathrm{~km}^{2}\right)$ of the surface of the sub-basins, which constituted a $0.32 \mathrm{~km}^{2}$ increase in comparison to 2005. However, an inverse pattern was found in SWD 2, with a slight reduction in areas covered by lakes and reservoirs. Table 4 and Figure 5 display the results of the mapping for 2015.

Table 4: Percentage (\%) of land use/coverage in sub-watersheds (SWDs) of lower Itapecuru River in 2015.

\begin{tabular}{cccccccccccc}
\hline Land use/occupation & SWD & SWD & SWD & SWD & SWD & SWD & SWD & SWD & SWD & SWD & TOTAL \\
classes & $\mathbf{1}$ & $\mathbf{2}$ & $\mathbf{3}$ & $\mathbf{4}$ & $\mathbf{5}$ & $\mathbf{6}$ & $\mathbf{7}$ & $\mathbf{8}$ & $\mathbf{9}$ & $\mathbf{1 0}$ & TO \\
\hline Fresh water & 0.85 & 0.35 & 0.18 & 0.09 & 0.69 & 0.31 & 1.05 & 0.08 & 0.20 & 0.45 & 0.44 \\
Agriculture & 0.56 & - & - & 0.04 & 0.15 & 0.06 & 1.17 & 0.54 & 0.20 & 0.30 & 0.29 \\
Floodplain & 1.68 & 0.67 & - & 3.67 & - & 1.36 & - & 1.61 & - & - & 0.85 \\
High occupation & 11.80 & - & - & - & - & - & - & - & - & 0.38 & 1.14 \\
Low occupation & 4.07 & 0.64 & 0.76 & 1.30 & 1.01 & 0.30 & 0.80 & 0.92 & 0.53 & 2.09 & 1.14 \\
Medium occupation & 1.15 & 0.07 & 0.73 & - & 1.09 & - & - & 0.67 & 0.00 & 2.94 & 0.67 \\
Exposed soil & 18.8 & 27.52 & 8.58 & 8.28 & 10.11 & 4.01 & - & 3.99 & 2.39 & 9.75 & 9.31 \\
High vegetation & 18.22 & 27.96 & 44.42 & 27.90 & 60.21 & 80.49 & 67.45 & 58.67 & 87.77 & 70.24 & 60.67 \\
Low vegetation & 20.86 & 13.44 & 6.51 & 6.37 & 14.57 & 3.00 & 1.00 & 5.29 & 2.39 & 7.28 & 7.62 \\
Medium vegetation & 22.05 & 29.35 & 38.81 & 52.36 & 12.17 & 10.37 & 28.53 & 28.23 & 6.52 & 6.58 & 17.88 \\
\hline
\end{tabular}




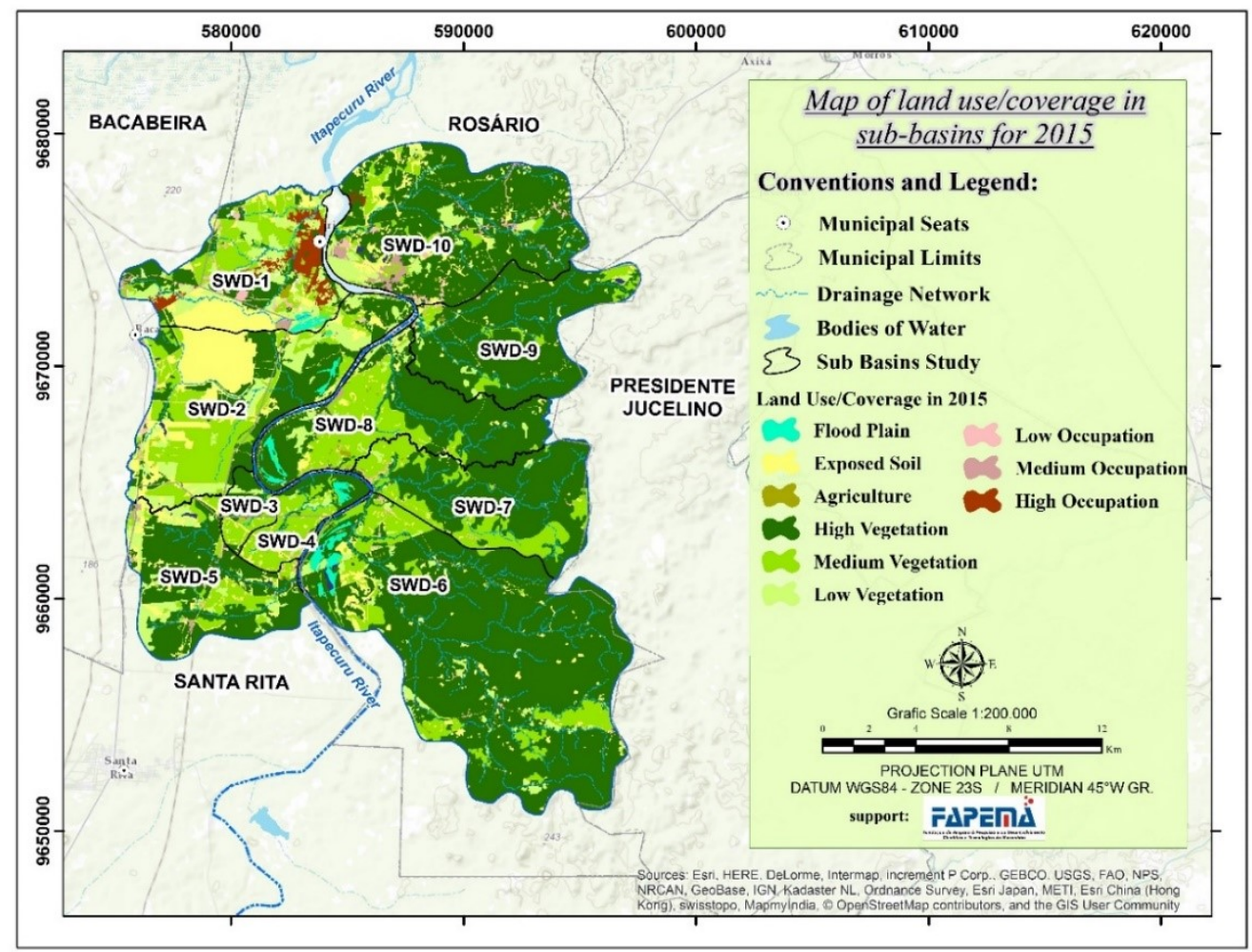

Figure 5: Map of land use/coverage in sub-watersheds of lower Itapecuru River for 2005-2015.

In 2015 , the high and medium vegetation classes continued to predominate, accounting for $78.6 \%$ of the sub-watersheds (331.14 $\mathrm{km} 2$ ). In comparison to 2010 , a $1.92 \%$ reduction in the arboreal component occurred, with the loss of $8.15 \mathrm{~km} 2$ of vegetation. The largest changes occurred in SWD 1, SWD 2 and SWD 10, with reductions of $1.56 \mathrm{~km} 2,2.63 \mathrm{~km} 2$ and $1.8 \mathrm{~km} 2$, respectively.

Areas of low vegetation increased by $1.8 \%$ in comparison to 2010 , corresponding to an area of $7.62 \mathrm{~km} 2$. This was likely due to the suppression of the regeneration of high and medium vegetation. The largest change occurred in SWD 1, with an increase from $5.75 \mathrm{~km} 2$ to $8.1 \mathrm{~km} 2$.

The largest changes in exposed soil between 2010 and 2015 occurred in SWD 1 and SWD 4 due to the expansion of areas deprived of vegetation. The proportion of this land coverage classification increased from $12 \%$ to $18.8 \%$ in SWD 1 and from $6.26 \%$ to $8.6 \%$ in SWD 4, with respective increases of $2.62 \mathrm{~km} 2$ and $0.23 \mathrm{~km} 2$. In SWD 1, the changes were related to urban expansion process in the municipalities of Rosário and Bacabeira. In SWD 4, the changes were likely due to the removal of vegetation for the implantation of subsistence farming activities.

High, medium and low occupation classes accounted for $2.94 \%(12.4 \mathrm{~km} 2)$ of the study area in 2015 , constituting a $0.23 \%$ increase in comparison to 2010 , which corresponded to $0.97 \mathrm{~km} 2$. SWD 1 and SWD 10 continued to be the most representative, with proportions of $17.02 \%$ and $5.4 \%$ of the respective sub-basins.

Agriculture accounted for $0.29 \%$ (1.22 km2) of the mapped area in 2015, with a reduction of 0.81 $\mathrm{km} 2$ in comparison to 2010 , denoting only a slight change in this sector. Moreover, no significant changes in the area of flood fields or bodies of water occurred between 2010 and 2015.

In the comparison of 2005 and 2015, the land use/coverage classes mapped for the subwatershedsof the lower Itapecuru River demonstrated small percentage variations (Figure 6). The main changes occurred in SWD 1 and SWD 2, with respective reductions of $4.78 \mathrm{~km} 2$ and $7.03 \mathrm{~km} 2$, totaling a loss of $11.81 \mathrm{~km} 2$ of areas of high and medium vegetation in a ten-year period. The reduction in green areas was accompanied by an increase in exposed soil of $5.53 \mathrm{~km} 2$ to $7.27 \mathrm{~km} 2$ in SWD 1 and $10.75 \mathrm{~km} 2$ to $14.76 \mathrm{~km} 2$ in SWD 2. The changes detected in these two sub-watersheds were mainly due to the removal of vegetation during the excavation stage of the implantation of the petrochemical enterprise and, to a lesser extent, urban expansion in the municipalities of Bacabeira and Rosário. 


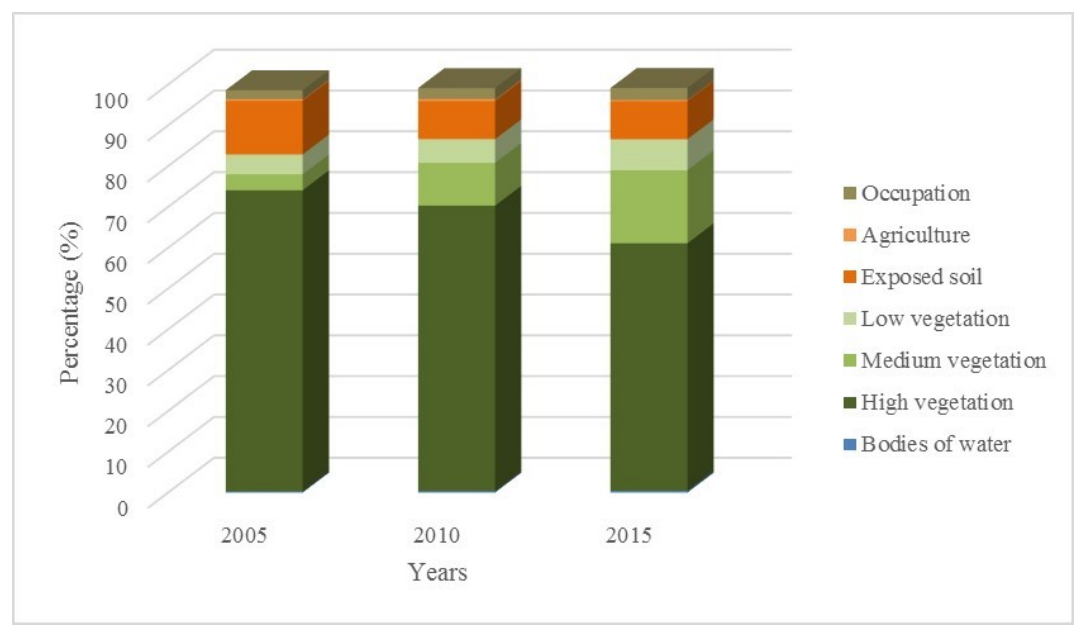

Figure 6: Comparison of land use/coverage in sub-watershedsof lower Itapecuru River between 2005 and 2015.

The changes in SWD 1 and SWD 2 are in agreement with data reported by Araújo (2013), who describes alterations in patterns of land use/coverage between 2000 and 2010 . The author found an $8.46 \%$ reduction in vegetation in SWD 1 and an $8.16 \%$ reduction in SWD 2, caused mainly by the onset of the implantation of the petrochemical enterprise, where a significant portion of the green area removed pertained to permanent preservation areas. Other impacts of this project were found in the Encyclopedia of the Municipalities of Maranhão: Geographic Micro-Region of Rosário, in the characterization of the current demographic context of the municipality of Bacabeira:

The population growth of 4409 inhabitants is partially due to the installation of the work site for the Premium I Refinery of PETROBRAS (Brazilian Petroleum Company S.A), which attracted laborers from other regions and even other states. Some problems arose with the installation of this enterprise, which altered the geographic space of the city, with the occurrence of land conflicts, real estate speculation, changes in the economic activities of the region, expropriations, improper land use, constructions, excavations and waste disposal sites (IMESC, 2014, p. 59).

Even with the changes seen in SWD 1 and SWD 2, the remaining sub-watersheds of the lower Itapecuru River exhibited significant percentages of arboreal vegetation, with no abrupt transformations of the landscape characteristics between 2005 and 2015. However, economic projections indicate that the expansion of the port in the city of São Luís will attract new enterprises that may be implanted in the region of the lower Itapecuru River due mainly to the proximity to and saturation of the industrial district of São Luís, the existence of areas unoccupied by humans and the proximity to the Itapecuru River (availability of water). This situation could impose increasing pressure on the natural resources of the study area, with the real possibility of the occurrence of significant changes in the patterns of the landscape, exerting a direct impact on the quality of life of local communities and the functioning of natural ecosystems.

Another important aspect regards the need for decision makers to establish strategies of territorial and environmental planning considering the river basin as a unit of analysis. This aspect is fundamental, as the sub-watersheds of the lower Itapecuru River are small, with a drainage network in which intermittent and first-order channels predominate. Together with the topography, these characteristics indicate the need for integrated planning, with the definition and implementation of strategies aimed at reconciling land use with the protection of natural ecosystems. Moreover, considering the morphometric characteristics, $83.3 \%$ of the sub-watersheds constitute zones of medium to high environmental susceptibility (SOARES et al, 2016).

The understanding of the dynamics of land use/coverage is a fundamental component to the planning of environmental management strategies in the region of the lower Itapecuru River. The information generated could assist in the design of proposals aims at properly organized land development, the indication of protected areas, the containment of erosive processes, the recovery of 
degraded ecosystems and the assurance of water quality, the consequences of which would be the preservation of the landscape characteristics and improved quality of life for local communities.

\section{CONCLUSION}

High and medium vegetation classes were predominant in the three years analyzed, accounting for $77.76 \%$ of the surfaces of the sub-watersheds in $2005,80.5 \%$ in 2010 and $78.6 \%$ in 2015 . Thus, despite exiting pressure in the region, the environment continues to exhibit extensive areas with a high potential for conservation. However, the maintenance of the integrity of these areas requires the implementation of environmental planning strategies.

The main changes in land use/cover patterns between 2005 and 2015 occurred in SWD 1, SWD 2 and SWD 10. Such changes were due to the removal of vegetation during the excavation stage of the petrochemical enterprise in the municipality of Bacabeira (SWD 1 and SWD 2). In SWD 10, the main modifying agent was the expansion of occupied areas in the municipality of Rosário.

Occupied areas (high, medium and low) increased $0.74 \%$ between 2005 and 2015, corresponding to $3.07 \mathrm{~km} 2$ of the surface of the mapping units. The major changes were found in SWD 1 and SWD 10 between 2005 and 2010 due to the implantation of the work site for the petrochemical enterprise, which was the driving force of the economy in the region at the time, leading to an increase in population density and the expansion of areas of high occupation.

Agricultural activities did not cause any significant changes in the landscape of the sub-basins. Moreover, the small sizes and distribution of activities indicate farming for the purposes of subsistence. Based on the mapping, variations occurred in the areas used for crops among the years analyzed, suggesting that the communities allowed areas of land to remain fallow to give the cultivated earth an opportunity to recover.

The area of flood fields diminished from $5.79 \mathrm{~km} 2$ in 2005 to $3.56 \mathrm{~km} 2$ in 2015 , with the greatest evidence of such reductions found in SWD 6, followed by SWD 8 and SWD 1. Management strategies that ensure this landscape unit are extremely important for the region due to the fact that they are part of the floodplains of the Itapecuru River, which are areas for fish reproduction as well as foraging groups for other animals and fishing grounds for the subsistence of local communities.

With the prospect of the implementation of large enterprises in the industrial district of the municipality of Bacabeira and other parts of the lower Itapecuru River, the characteristics of the landscape could undergo significant changes if effective environmental planning strategies are not put into place, leading to a negative impact on the quality of life of local communities and the functioning of natural ecosystems. As a priority measure, the river basin should be adopted as an environmental planning unit. Moreover, proposals should consider the natural characteristics of the environment and its support capacity to ensure the maintenance and perenniality of ecosystemic services.

\section{ACKNOWLEDGEMENTS}

The authors thank the Fundação de Amparo à Pesquisa e ao Desenvolvimento Científico e Tecnológico do Maranhão (FAPEMA) for the financial support to the accomplishment of this work.

\section{REFERÊNCIAS}

ALCANTARA, E. H. Caracterização da Bacia Hidrográfica do Rio Itapecuru, Maranhão - Brasil. Caminhos da Geografia, v. 7, n. 11, p. 97-113, 2004.

ARAÚJO, G. M. (2013). Avaliação da Sustentabilidade Ambiental das sub-bacias dos Riachos Seco e Precuá, nos municípios de Bacabeira e Rosário - MA: Bases para o ordenamento territorial. Master's Thesis, Universidade Federal do Maranhão, Maranhão, Brasil. p. 104. 2013.

BARROS, K. O.; MARCATTI, G. E.; COSTA, F. R.; OLIVEIRA, J. C.; RIBEIRO, C. A. A. S.; SOARES, V. P.; SILVA, E. Análise temporal das classes de uso e ocupação da terra na bacia hidrográfica do Rio Vieira, Montes Claros, Minas Gerais. Revista Agrogeoambiental, v. 5, p. 43-54, 2013. http://dx.doi.org/10.18406/2316-1817v5n22013441 
BEZERRA, I. S.; SILVA, T. C. Análise de riscos à perda de solo para diferentes cenários de uso e ocupação na bacia hidrográfica do Rio Abiaí-Papocas. Revista Brasileira de Recursos Hídricos, v. 9, p. 95-204, 2014. http://dx.doi.org/10.21168/rbrh.v19n4.p195-204

BOTELHO, R. G. M.; SILVA, A. S. Bacia hidrográfica e qualidade ambiental. In: VITTE, A. C.; GUERRA, A. J. T. (Orgs.). Reflexões sobre a Geografia Física no Brasil. Rio de Janeiro: Bertrand, 2010. p. 153-192.

DEMARCHI, J. C.; ZIMBACK, C. R. L. Mapeamento, erodibilidade e tolerância de perda de solo na sub-bacia do Ribeirão das Perobas. Revista Energia Agrícola, v. 29, p. 102-114, 2014. http://dx.doi.org/10.17224/EnergAgric.2014v29n2p102-114

DSG-SUDENE. Divisão do Serviço Geográfico do Exército Nacional-Superintendência do Desenvolvimento do Nordeste. (1980). Cartas Planialtimétricas na escala 1:100.000, folhas 549 e 610. Escala: 1:100.000. Retrieved from <http://www.zee.ma.gov.br/html/cart1.html>. Access in: 10 nov. 2016.

FSADU. Fundação de Apoio ao Desenvolvimento da Universidade Federal do Maranhão. Estudo de Impacto Ambiental-EIA/Relatório de Impacto do Meio Ambiente-RIMA da Refinaria Premium I. Volume 2: Meio Físico. São Luís/MA: UFMA. 2008. 440 p.

FSADU. Fundação de Apoio ao Desenvolvimento da Universidade Federal do Maranhão. Estudo de Impacto Ambiental-EIA/Relatório de Impacto do Meio Ambiente. RIMA da Refinaria Premium I. Banco de Dados. São Luís/MA: UFMA. 2009.

FSADU. Fundação de Apoio ao Desenvolvimento da Universidade Federal do Maranhão. Relatório de Acompanhamento das Principais Cadeias Produtivas da Região de Entorno da Refinaria Premium I. Produto 7 - Relatório Final. São Luís/MA: UFMA. 188 p. 2013.

IBGE. Instituto Brasileiro de Geografia e Estatística. Subsídios ao zoneamento ecológicoeconômico da bacia do rio Itapecuru - MA: diretrizes gerais para ordenação territorial. Primeira Divisão de Geociência do Nordeste. Rio de Janeiro: IBGE, 1998. 187 p.

IBGE. Instituto Brasileiro de Geografia e Estatística. Mapas Temáticos do IBGE: Solos. 2007. Retrieved from <ftp://geoftp.ibge.gov.br/mapas_tematicos/solos>. Access in: 10 nov. 2016.

IBGE. Instituto Brasileiro de Geografia e Estatística. Mapa de Infraestrutura de Transporte. 2010. Retrieved from <http://www.ibge.gov.br/home/geociencias/geog rafia/mapas_doc4.shtm>. Access in: 10 nov. 2016.

IBGE. Instituto Brasileiro de Geografia e Estatística. Manual Técnico de Uso da Terra. 3nd ed. Rio de Janeiro: IBGE, 2013. $171 \mathrm{p}$.

IBGE. Instituto Brasileiro de Geografia e Estatística. IBGE Cidades. 2015. Retrieved from http://www.cidades.ibge.gov.br/xtras/home.php. Access in: 22 nov. 2016.

IMESC. Instituto Maranhense de Estudos Socioeconômicos e Cartográficos. Enciclopédia dos Municípios Maranhenses: microrregião geográfica de Rosário. São Luís: IMESC, 2014. 238 p.

INMET. Instituto Nacional de Meteorologia. Estações de dados. 2015. Retrieved from http://www.inmet.gov.br/portal/index.php?r=estacoes/estacoesAutomaticas. Access in: 5 out. 2016.

INPE. Instituto Nacional de Pesquisas Espaciais. TOPODATA: Banco de Dados Geomorfométricos do Brasil. 2008. Retrieved from <www.dsr.inpe.br/topodata>. Access in: 17 out. 2016.

INPE. Instituto Nacional de Pesquisas Espaciais. Imagem LANDSAT TM e ETM. 2009. Retrieved from <www.dgi.inpe.br/siteDgi/ATUS_LandSat.php>. Access in: 19 fev. 2017.

INPE. Instituto Nacional de Pesquisas Espaciais. Catalogo de Imagens. 2015. Retrieved from <http://www.dgi.inpe.br/CDSR/> Access in: 10 jul. 2016.

LABGEO. Laboratório de Geoprocessamento da Universidade Estadual do Maranhão. Atlas do Maranhão. São Luís: GEPLAN, 2002. 44 p. Retrieved from <https://www.passeidireto.com/arquivo/17533587/atlas-do-maranhao-2002> Access in: 08 jan. 2017. 
MELO, J. A. B.; LIMA, E. R. V.; PEREIRA, R. A.; DANTAS-NETO, J. Identificação das Áreas de Conflito de Uso da Terra na Microbacia do Riacho do Tronco, Boa Vista, PB. Revista de Geografia, v. 27, p. 185-201, 2010.

MENESES, B. M.; REIS, R.; VALE, M. J.; SARAIVA, R. Land use and land cover changes in Zêzere watershed (Portugal) - Water quality implications. Science of the Total Environment, v. 527-528, p. 439-447, 2015. http://dx.doi.org/10.1016/j.scitotenv.2015.04.092

MIGUEL, A. E.; MEDEIROS, R. B.; BRUGNOLLI, C. A. C.; OLIVEIRA, W. Análise do Uso da Terra e Cobertura Vegetal na Bacia do Ribeirão do Meio, Brasilândia/MS. Revista Brasileira de Geografia Física, v. 5, p. 1088-1098, 2012.

NERY, C. V. M.; BRAGA, F. L.; MOREIRA, A. A.; FERNANDES, F. H. S. Aplicação do Novo Código Florestal na Avaliação das Áreas de Preservação Permanente em Topo de Morro na Sub-Bacia do Rio Canoas no Município de Montes Claros/MG. Revista Brasileira de Geografia Física, v. 6, p. 1673-1688, 2013.

NUGEO. Núcleo Geoambiental da Universidade Estadual do Maranhão. Bacias Hidrográficas: Subsídios para o planejamento e a gestão territorial. Relatório Técnico. 2011. 47 p.

PACHECO, F. A. L.; VARANDAS, S. G. P., SANCHES FERNANDES, L. F.; VALLE JUNIOR, R. F. Soil losses in rural watersheds with environmental land use conflicts. Science of the Total Environment, v. 485-486, p. 110-120, 2014. http://dx.doi.org/10.1016/j.scitotenv.2014.03.069

REIS, A. A.; TEIXEIRA, M. D.; ACERBI JÚNIOR, F. W.; MELLO, J. M.; LEITE, L.R.; SILVA, S. T. Land Use and Occupation Analysis of Permanent Preservation Areas in Lavras County, MG. Ciência e Agrotecnologia, v. 36, p. 300-308, 2012. http://dx.doi.org/10.1590/S1413-70542012000300005

SHI, Z. H.; AI, L.; LI, X.; HUANG, X. D.; WU, G.L.; LIAO, W. Partial least-squares regression for linking land-cover patterns to soil erosion and sediment yield in watersheds. Journal of Hydrology, v. 498, p. 165-176, 2013. http://dx.doi.org/10.1016/j.jhydrol.2013.06.031

SOARES, L. S.; LOPES, W. G. R.; CASTRO, A. C. L.; ARAÚJO, G. M. Análise morfométrica e priorização de bacias hidrográficas como instrument de planejamento ambiental integrado. Revista do Departamento de Geografia, v. 31, p. 82-100, 2016. http://dx.doi.org/10.11606/rdg.v31i0.107715

SOUZA, V.; GALVANI, E.; SOUZA, M. L. Determinação e Adequação da Capacidade de Uso da Terra em Bacia Hidrográfica por Meio de Sistematização Metodológica no SIG SPRING. Geografia (Londrina), v. 24, p. 55-69, 2015. 